\title{
Internet voting from abroad: exploring turnout in the 2014 French consular elections
}

\author{
Régis Dandoy ${ }^{1,2,3} \cdot$ Tudi Kernalegenn ${ }^{4}$
}

Accepted: 20 March 2021 / Published online: 3 May 2021

(c) The Author(s), under exclusive licence to Springer Nature Limited 2021

\begin{abstract}
Internet voting has been available for French citizens living abroad since 2006, and $43.21 \%$ of them filled out their ballots online for the first election of their consular delegates in 2014. Using a multivariate analysis of turnout figures at the district and country levels, this research note explores if ballot box and Internet voters differ in their electoral participation patterns. It concludes that turnout must be understood based on the voting modality that French voters choose. While the characteristics of the electoral district (community size, geographical, and historical proximity with France, and party competition) impact ballot box voter turnout, Internet voter turnout is most influenced by the host country's economic and infrastructure development.
\end{abstract}

Keywords Internet voting · External voting $\cdot$ Turnout $\cdot$ Consular elections $\cdot$ French emigrants

\section{Introduction}

France is among the world's pioneers of using Internet voting, given French citizens living abroad have been able to vote online since 2006 for select elections. Since low turnout has become worrisome in France, Internet voting is meant to make the voting process easier for citizens, in turn, it presents an opportunity to increase

Régis Dandoy

rdandoy@usfq.edu.ec

Tudi Kernalegenn

tudi.kernalegenn@uclouvain.be

1 Universidad San Francisco de Quito, Quito, Ecuador

2 Université Libre de Bruxelles, Bruxelles, Belgium

3 Waseda University, Tokyo, Japan

4 Institut de Sciences Politiques Louvain-Europe (ISPOLE), UCLouvain, Louvain-la-Neuve, Belgium 
participation. However, as Internet voting has also raised concerns about safety, security, and voting secrecy, this voting modality has suffered setbacks in recent years. As of 2021, Internet voting in France is only available for the elections of consular councillors for French citizens abroad. This research note aims to focus on electoral participation patterns across districts and countries by observing turnout in the 2014 elections of French consular councilors, for which Internet voting was widely used.

Most democracies have enfranchised their diaspora through allowing various forms of extraterritorial voting (Collyer and Vathi 2007; Turcu and Urbatsch 2015). Alongside the spread of emigrant voting, immigrant voting is also implemented at various levels across the globe (see, e.g., Finn 2020). There is a burgeoning literature on long-distance citizenship and elections. It has tackled many dimensions of this phenomenon, including the reasons and modalities of implementing such 'expansive citizenship' (Bauböck 2007; Lafleur 2013; Turcu and Urbatsch 2015; Hutcheson and Arrighi 2015; Caramani and Grotz 2015; Hartmann 2015), as well as the determinants of, and sociology behind, long-distance electoral participation (Collyer 2014a; Belchior et al. 2018; Ciornei and Østergaard-Nielsen 2020; Burgess and Tyburski 2020; Goldberg and Lanz 2019).

Such literature nonetheless contains blind spots and shortcomings. Notably, it focuses essentially on national elections, with a few exceptions, such as Arrighi and Lafleur's (2019) study of the expatriates' vote in regional elections. This calls for more research on expatriates' electoral participation in other types of elections, beyond national ones. A second relative blind spot is the impact of long-distance elections on the territoriality of voting (Collyer 2014a). Scholars have already suggested how important postal and Internet voting is in long-distance elections for increasing electoral turnout, since it facilitates the act of voting (Belchior et al. 2018; Hutcheson and Arrighi 2015; Ciornei and Østergaard-Nielsen 2020; Fowler 2020; Germann 2021). However, not much research has focused on this (Petitpas et al. 2020). Studying the uptake and effects of voting modalities is not only interesting per se but analyzing the use of Internet voting in a long-distance context can also shed light on more generally assessing technical evolutions in voting.

French consular elections, which have only taken place once so far, in 2014, serve as a relevant case study for four reasons. First, only a scarce literature exists on the political life of emigrants from developed countries since the transnational politics literature focuses essentially on emigrants from lesser developed countries in developed countries. Second, France has a highly developed political system representing expatriates (Pellen 2013; Collard 2013; Kernalegenn and Pellen 2020) and understanding it better is essential. Third, almost no literature analyzes the local representation of expatriates, despite its prevalence (Gamlen, Cummings and Vaaler 2019; Gamlen 2019). Notably, consular councilors elections have never been studied for their own sake, and rarely mentioned in the literature. Finally, this paper contributes insights into a different system of representation and type of elections by analyzing Internet voting in a country that has become relatively hostile to the modality (Collard and Fabre 2014).

To the best of our knowledge, consular councils and consular elections are diaspora institutions and elections on which almost no literature has been devoted so 
far. If this family of institutions is relatively rare at the moment, it is not specific to France. There is, for instance, the Consejos de Residentes Españoles en el Extranjero (Councils of Spanish Residents Abroad, since 1987), the Comitati degli Italiani all'estero (Committees of Italians abroad, since 1989), and the Conselhos consultivos da área consular (Portuguese Consular advisory councils, since 2009). We therefore offer a novel contribution for studying consular representative systems and, more generally, emigrant local representation.

Internet voting has also been largely overlooked in the literature, especially the French context and for external voting. As of 2021, about ten countries worldwide use Internet voting for (at least some of) their political elections. While some scholarly knowledge exists about Internet voters and their voting behavior (see, e.g., Serdült et al. 2015), very few countries have applied Internet voting for their citizens living abroad. Even if several countries have used Internet voting abroad (e.g., Armenia, Estonia, the Netherlands, Norway, Panama, and Portugal, as well as at some subnational levels in Australia, Switzerland, and the United States [USA]), the literature on Internet voting from abroad remains in its infancy (for exceptions, see Germann and Serdült 2014; Collard and Fabre 2014; Fowler 2020; Germann 2021). This includes the French case since another type of electronic voting-the DREs or 'machines à voter' - has attracted most of the academic attention on this country. This type of electronic voting has been used since 2004 in about 60 French municipalities for a variety of political elections.

The following Sect. 1 introduces external voting, the political representation of French citizens abroad, and the 2014 consular elections. Section 2 presents the data collection process and the main variables. Section 3 explores the explanatory patterns of electoral participation at the district and country levels. Section 4 focuses on the phenomenon of Internet voting in the 2014 consular elections by investigating Internet voter turnout figures, using aggregate data. This research note demonstrates that while electoral district characteristics (community size, geographical and historical proximity with France, and party competition) impact ballot box voter turnout, emigrants' Internet voter turnout is above all influenced by the host country's economic and infrastructure development. A conclusion summarizes the findings and suggests future studies and comparisons.

\section{Representing French citizens abroad and holding consular elections}

France is one of the European countries with the lowest proportion of emigrants, with an estimated two million French citizens living abroad and, of those, 1,680,594 were registered to vote in 2014 (i.e., $2.5 \%$ of the French population). ${ }^{1}$ Despite low numbers, French emigrants represent an expatriate community endowed with extensive political rights in their home country (Garriaud-Maylam 2010; Collard 2013; Kernalegenn and Pellen 2020). They retain the right to vote in elections from

\footnotetext{
1 https://www.ufe.org/actualites/statistiques-des-francais-de-letranger-2014 (last accessed on 13 July 2020).
} 
abroad; since 1976-1977, they have been allowed to vote from abroad for national referendums, presidential, and European elections; since 2008, they can also vote for parliamentary elections. Electoral registration is very easy, since the electoral registry is automatically drawn from the consular population registry (Arrighi 2018).

French citizens living abroad also enjoy substantial political representation in their home country (Collyer 2014b). Since 1946, 12 senators (out of 348) in the upper house of the French Parliament represent those abroad. A special political body was created in 1948 to advise the government on all issues involving French emigrants. The members of this Conseil supérieur des Français de l'étranger (High Council of French Citizens Abroad-CSFE), renamed in 2004 as Assemblée des Français de l'étranger (Assembly of French Citizens Abroad-AFE), meet twice a year in plenary sessions in Paris. Its role is to advise the government on issues, problems, and projects of interest to French people overseas and to strengthen France's presence abroad. Additionally, in 2008 French emigrants were granted direct representation in the National Assembly, which is the lower house of the French Parliament. In the 2012 legislative election, French expatriates were called on for the first time to elect 11 Members of Parliament (MPs), one per extraterritorial constituency. Finally, 443 consular councilors were established in 2014. These 'local' representatives are directly elected in 130 extraterritorial constituencies, and they advise local consuls. While French residents abroad directly elected the 90 AFE members between 1982 and 2014, the consular councilors now select them (Kernalegenn and Pellen 2020) (Fig. 1).

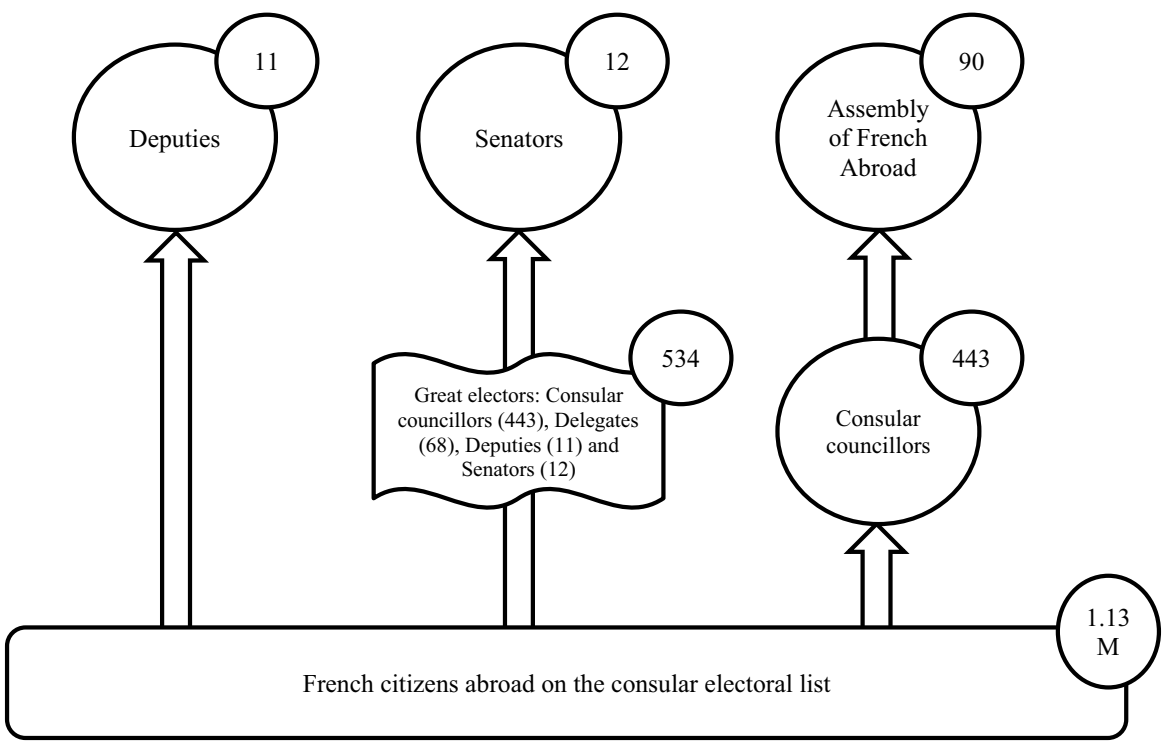

Fig. 1 The system of political representation for French residents abroad 
The consular councils were established by Law $\mathrm{N}^{\circ} 2013-659$ of 22 July $2013^{2}$ that focuses on the representation of French citizens who reside outside of France. It states that the consular council is "responsible for formulating opinions on consular matters or matters of general interest, in particular cultural, educational, economic and social, concerning the French [citizens] established in the district" (art. 3). Their most concrete tasks are allocating scholarships to French students throughout the network of French schools abroad, providing social assistance to French people in need, supporting the volunteer sector, and attending to security issues (Lequesne 2020).

To elect the consular councilors, whose mandate lasts six years, ${ }^{3}$ three voting methods are possible: in-person, proxy, and Internet voting. ${ }^{4}$ Internet voting occurred between 14 and 20 May 2014. Voting in ballot boxes took place in offices abroad opened by French embassies and consulates on 24 May 2014 in the Americas and the next day in the rest of the world, i.e., on the same day as the European elections (for which citizens abroad could also vote but not via Internet voting).

The election consisted of choosing 443 consular councilors and 68 delegates in 130 consular constituencies. The number of consular councilors varies from one to nine: on the low end, 22 councils have just one consular councilor. On the other end, three have nine councilors: the second district of the United Kingdom (including London), the Belgian district, and the second district of Switzerland (i.e., Frenchspeaking Switzerland). In electoral districts where a single seat is to be filled, the election uses a first past the post system. In electoral districts where several seats are to be filled, the election relies on a list-based ballot, with proportional representation based on the rule of the highest average. In the most populated electoral districts, consular delegates are elected at the same time as the consular councilors to correct for the population differences between districts. Their only purpose is to fill the electoral body for senators who represent the French abroad, e.g., the second Swiss district is composed of nine consular councilors and 12 consular delegates.

France implemented its Internet voting system for the first time in the 2006 election of AFE members, ${ }^{5}$ who were then still directly elected by all registered French overseas voters (Collard 2013). Only 10,201 voters used this modality (Collard and Fabre 2014). Afterward, reports by the ADFE (Association démocratique des Français de l'étranger - the so-called Pellegrini report) and UFE (Union des Français de l'Étranger - the so-called Lang report) both expressed serious doubts about the verifiability, transparency, and sincerity of Internet voting.

Nevertheless, a decree on 12 May 2009 authorized its more widespread use. Internet voting was then again used in the AFE elections of 2009 and 2010 (byelection). It was also applied for the 2012 legislative election in the 11 newly created

\footnotetext{
2 https://www.legifrance.gouv.fr/affichTexte.do?cidTexte=JORFTEXT000027734839.

3 Renewing the consular councils was scheduled for 17 May 2020 but due to the Covid-19 crisis, they have been postponed to 29 and 30 May 2021. Consequently, the mandate of the 443 consular councilors has been prolonged for a seventh year, until May 2021 (Law N ${ }^{\circ} 2020-760$ of 22 June 2020).

${ }^{4}$ Decree $N^{\circ}$ 2014-290 dated 4 March 2014 relates to the electoral provisions for the representation of French nationals living outside of France.

5 This occurred after a first test in 2003 in two districts in the US (Collard and Fabre 2014).
} 
constituencies for French citizens living abroad, alongside in-person, proxy, and postal voting. By then, Internet voting had become popular among voters, given $57 \%$ chose to vote online for the first round and $53.6 \%$ for the second round (Collard and Fabre 2014). ${ }^{6}$ Thereafter, Internet voting was again available to use in the 2014 consular election. In parallel to traditional polling stations in consulates and embassies, an electronic voting polling station was set up, which aimed to oversee the voting process with the Internet and come to a stop if a security threat or hacker attack arose. Internet voters were asked to indicate their vote a few days before election day, thereafter identifying them, to ensure Internet voters could not emit a second vote physically or by proxy on election day.

To vote with the Internet in consular elections, French voters needed to be registered on the consular electoral list. This registration is done automatically based on the registry of French living abroad (Registre des Français établis hors de France), for which one can register online or in-person in French consulates and embassies. During registration, voters were required to provide their postal address, a valid e-mail address, and phone number. These three elements are essential as logins and passwords are communicated to the voters by mail, e-mail, and SMS.

Many critiques were expressed about Internet voting after the 2014 consular elections. The most prominent stemmed from two Senate reports that outlined connection problems (Frassa and Leconte 2015; Deromedi and Détraigne 2018). First, it had been difficult to send logins and passwords to voters since around $25 \%$ of registered voters had failed to provide an e-mail address, whereas others in several countries never received the information sent by post and SMS. Second, 6\% of Internet voters (i.e., around 4,630 citizens) contacted support services because they encountered connection problems. In addition to these two issues, an uptick in those connecting within the last few hours before Internet voting ended saturated the voting platform, rendering it inaccessible for about two hours. The consequences of how these three phenomena affected voting behavior and election results remain unexplored, although they likely contributed to the low participation rate.

\section{Data and methods}

To explore the results of the 2014 consular elections, we built a database measuring the patterns of electoral demand at the district level $(N=130)$, based on official elections records from the French Ministry of Europe and Foreign Affairs. ${ }^{7}$ While 130 districts exist, there were no candidates (therefore no election) in the Ukraine district, ${ }^{8}$ so our turnout analysis entails 129 districts. We are aware that

\footnotetext{
${ }^{6}$ Internet voting has also been used within the French territory for other types of elections, e.g., professional polls in banks and chambers of commerce; it has also been used for party internal primary elections of the UMP in Paris in 2010.

${ }^{7}$ https://www.data.gouv.fr/fr/datasets/resultats-des-elections-des-conseillers-consulaires-de-2014/ (last accessed on 24 May 2020).

${ }^{8}$ French citizens living in Ukraine remained without consular representation during the whole term (2014-2021).
} 
our measurement of electoral participation at the aggregate level (i.e., at the level of electoral districts) may cancel individual idiosyncrasies and variation in the demographic composition of the electorate.

Electoral districts used in the consular elections do not always correspond to host countries. Large host countries or countries containing a large French community are subdivided into different electoral districts-e.g., there are no less than nine electoral districts in the US and six in Morocco. On the contrary, several smaller host countries or countries with small French communities are grouped into one electoral district-e.g., the Kenya district covers French voters living in seven East African countries (Burundi, Kenya, Rwanda, Uganda, Tanzania, Zambia, and Zimbabwe). Since districts are not clustered into countries, the collected data are not in a hierarchical structure, preventing us from performing multilevel analyses.

We differentiate between two main operationalizations of turnout. First, overall turnout measures the percentage of voters who participated in the consular elections, based on the total number of registered voters in a district. Second, effective turnout accounts for invalid votes (i.e., blank and null votes) when calculating turnout: it is measured as the number of valid votes divided by the total number of registered voters. This differentiated operationalization of electoral participation into overall and effective turnout follows recent relevant work (see, e.g., Barnes and Rangel 2018; and Galam 2018 for French elections). Distinguishing between overall and effective turnout is particularly pertinent when comparing paper versus Internet voting, as the use of voting machines constitutes an effective method for reducing voter errors and uncounted ballots (Alvarez and Hall 2008; Germann 2020). This empirical link between e-voting and the share of invalid votes has been confirmed for various countries, such as Belgium (Dandoy 2014; Dejaeghere and Vanhoutte 2016), Brazil (Nicolau 2015; Fujiwara 2015; Katz and Levin 2018), India (Desai and Lee 2019), the Netherlands (Allers and Kooreman 2009), and the USA (Kimball et al. 2004; Stewart 2006). Given that this note focuses on Internet voting, we also test the impact our independent and control variables have on the share of Internet voters per district.

Several independent variables are included in the explorative OLS regression models. The first set of variables is measured at the district level. Following Dahl and Tufte (1973) on the impact of community size on turnout-i.e., the larger the size of the community, the lower the expected turnout. We include a variable measuring the importance of the French community by using the number of citizens officially registered in the French consulate (data from the Ministry of Europe and Foreign Affairs). We rescaled this variable by using its natural logarithm. We do not include the number of registered voters in each electoral district because of collinearity with this variable. ${ }^{9}$

We also add variables to better account for expatriates' situations in the host country by measuring linkages between the home and host countries' geographical and cultural distances. It is expected that the stronger the cultural and geographical

\footnotetext{
9 We ran alternative models using the number of registered voters as an independent variable, which did not affect the models' explanatory power.
} 
linkage between France and the host country, the higher turnout from abroad in consular elections. However, the opposite could also hold true, as greater distances from France may indicate that citizens require more consular assistance and presence. We measure the geographical distance in kilometers (rescaled by calculating its natural logarithm) between France's capital Paris and the city where the French consulate or embassy is located in the district. This provides an objective measure of the perceived distance between the host country district and the main place where French politics takes place and where most political parties are established. Given remittances are secondary in the French context, our linkages measurement is complemented by a variable on cultural proximity and on the common cultural environment that might influence French expatriates. We add a dummy variable for districts where French is (one of) the official language(s) ${ }^{10}$ or where more than $30 \%$ of the population is French-speaking, according to the definition of the Francophone linguistic space (La Francophonie 2014). The hypothesis is that turnout will be higher in French-speaking districts, due to a stronger cultural link between the home and host societies.

Finally, we also test the impact of party competition on turnout by considering the number of lists and candidates participating in consular elections in each district. No less than 395 lists were presented in the 130 districts, meaning that on average there was slightly more than three lists per electoral district. Electoral supply varied from no lists in the Ukraine district to nine in the fourth Canadian district (Montreal). In seven other districts, there was only one list presented to the voters, so in most of the districts $(93.89 \%)$ these elections concerned at least two lists. The 2014 consular elections were indeed competitive, and we expect that increased party competition would incentivize French voters to turn out.

The second set of independent variables relates to the host country's characteristics. ${ }^{11}$ We measure the size of the host country with figures of the natural logarithm of its total population (source: United Nations Population Division). The country's economic status is evaluated with GDP per capita (PPP, constant 2011 international \$ from the World Bank). Its development is measured by both the United Nation's Human Development Index (HDI) and the percentage of individuals using the Internet (based on the World Telecommunication/ICT Indicators Database). Given the high multicollinearity between these variables and, considering our focus on Internet voting, we retained only the use of the Internet in our models. We expect that the higher the use of Internet in the host country, the higher Internet turnout will be. Democracy in the host country is assessed by using the V-Dem score of electoral democracy index ( $v 2 x$ polyarchy). We expect that the higher quality of democracy in a host country, the higher overall turnout figures will be observed.

\footnotetext{
${ }^{10}$ For countries with different electoral districts, we coded this variable accordingly. For instance, the two electoral districts of Montreal and Quebec were considered as French speaking, unlike Toronto and Calgary.

11 Even if most electoral districts concern French nationals living in only one country, there are instances where the electoral districts cover several countries. In that case, we used data on the largest country. For instance, data on the electoral district composed of Romania and Moldova only contain information on Romania.
} 
Table 1 Exploring turnout and internet voting in the 2014 consular elections

\begin{tabular}{|c|c|c|c|c|c|c|c|}
\hline \multirow{2}{*}{$\begin{array}{l}\text { Vari- } \\
\text { ables }\end{array}$} & & \multicolumn{2}{|c|}{ Overall turnout } & \multicolumn{2}{|c|}{ Effective turnout } & \multicolumn{2}{|c|}{ Share of Internet voters } \\
\hline & & Model 1 & Model 2 & Model 3 & Model 4 & Model 5 & Model 6 \\
\hline \multirow{8}{*}{$\begin{array}{l}\text { Dis- } \\
\text { trict- } \\
\text { level }\end{array}$} & $\begin{array}{l}\text { Commu- } \\
\text { nity size }\end{array}$ & $-4.230 * * *$ & $-4.213 * * *$ & $-3.911 * * *$ & $-3.955^{* * *}$ & $9.045^{* * * *}$ & $2.688 *$ \\
\hline & & $(0.535)$ & $(0.649)$ & $(0.531)$ & $(0.641)$ & (1.001) & (1.101) \\
\hline & $\begin{array}{c}\text { Distance } \\
\text { with } \\
\text { Paris }\end{array}$ & $-1.455^{* *}$ & $-1.457^{*}$ & $-1.366^{* *}$ & $-1.386^{*}$ & -0.594 & $2.538^{*}$ \\
\hline & & $(0.591)$ & $(0.838)$ & $(0.586)$ & $(0.829)$ & (1.106) & (1.237) \\
\hline & $\begin{array}{l}\text { French- } \\
\text { speaking }\end{array}$ & 0.817 & -2.999 & 0.927 & -2.844 & $-16.15^{* * *}$ & -0.516 \\
\hline & & $(1.170)$ & $(1.829)$ & $(1.160)$ & $(1.808)$ & $(2.188)$ & $(2.696)$ \\
\hline & $\begin{array}{l}\text { Number of } \\
\text { lists }\end{array}$ & $1.530 * * *$ & $1.309 * * *$ & $1.647 * * *$ & $1.407 * * *$ & -0.853 & -0.837 \\
\hline & & $(0.449)$ & $(0.442)$ & $(0.445)$ & $(0.437)$ & $(0.840)$ & $(0.667)$ \\
\hline \multirow{6}{*}{$\begin{array}{c}\text { Coun- } \\
\text { try- } \\
\text { level }\end{array}$} & $\begin{array}{l}\text { Population } \\
\text { size }\end{array}$ & - & 0.0275 & - & 0.0851 & - & $2.101^{* * *}$ \\
\hline & & & $(0.351)$ & & $(0.347)$ & & $(0.512)$ \\
\hline & $\begin{array}{c}\text { Internet } \\
\text { use }\end{array}$ & - & $0.0527 *$ & - & $0.0545^{*}$ & - & $0.270^{* * *}$ \\
\hline & & & $(0.0299)$ & & $(0.0296)$ & & $(0.044)$ \\
\hline & $\begin{array}{l}\text { Democ- } \\
\text { racy }\end{array}$ & - & -2.336 & - & -2.017 & - & $8.232 *$ \\
\hline & & & $(2.342)$ & & $(2.315)$ & & $(3.428)$ \\
\hline \multirow[t]{5}{*}{ Control } & $\begin{array}{c}\text { Colonial } \\
\text { past }\end{array}$ & - & $7.599 * * *$ & - & $7.778 * * *$ & - & -1.685 \\
\hline & & & (1.973) & & $(1.950)$ & & $(2.957)$ \\
\hline & $\begin{array}{l}\text { EU mem- } \\
\text { ber }\end{array}$ & - & 0.0587 & - & 0.0725 & - & $9.360 * *$ \\
\hline & & & $(2.029)$ & & $(2.005)$ & & $(2.957)$ \\
\hline & $\begin{array}{l}\text { Overall } \\
\text { turnout }\end{array}$ & - & - & - & - & - & $\begin{array}{l}-0.386^{* *} \\
(0.134)\end{array}$ \\
\hline \multirow{4}{*}{$\begin{array}{l}\text { Model } \\
\text { sum- } \\
\text { mary }\end{array}$} & Constant & $64.90 * * *$ & $62.91 * * *$ & $60.02 * * *$ & $57.84 * * *$ & $-30.43^{* *}$ & $-39.33^{*}$ \\
\hline & & (7.868) & $(9.270)$ & (7.799) & (9.163) & (14.71) & (15.91) \\
\hline & $\begin{array}{l}\text { Observa- } \\
\text { tions }\end{array}$ & 129 & 129 & 129 & 129 & 129 & 129 \\
\hline & R-squared & 0.342 & 0.430 & 0.318 & 0.411 & 0.564 & 0.772 \\
\hline
\end{tabular}

Standard errors in parentheses. $* * * p<0.01, * * p<0.05, * p<0.1$

Regarding control variables, and similar to Ciornei and Østergaard-Nielsen (2020), we include a dummy for electoral districts in countries belonging to the European Union. This is important since French citizens abroad voted on the same 
day for both France's 2014 consular elections and the European elections. Possible cross-influences of the two electoral campaigns may have (positively) affected turnout. We also add another dummy variable for countries relating to France's colonial past (Second French colonial empire), i.e., countries that have gained their independence from France since 1945. Similar to the effects of speaking French, we expect the colonial connection to reinforce turnout. Finally, we also add overall turnout as a control variable in the model exploring the share of internet voters (for descriptive statistics on these variables, see Table 3 in the Appendix).

\section{Turnout in the 2014 consular elections}

To explore variation of electoral participation in the 2014 consular elections, our models distinguish between two different measurements of turnout: overall versus effective turnout (see Table 1). First, we looked at overall turnout figures for all 129 districts where elections were held. Turnout was low in the 2014 consular elections, averaging $20.61 \%$, but with large variation across districts, from $6.79 \%$ in the second Israeli district (Tel Aviv) ${ }^{12}$ to $51.75 \%$ in the second Indian district (Pondicherry).

Regarding overall turnout, our models show that five phenomena partially explain it. Turnout in consular elections is negatively affected by the size of the French community in the district, confirming previous studies where turnout is lower in larger districts with a larger population or number of registered voters. Geographical distance with Paris has a weak but negative impact on turnout, confirming our hypothesis, while party competition similarly influences turnout with each additional list being associated with an increase in turnout of about $1.5 \%$. At the country-level, economic and human development is associated with higher overall turnout. Using an indicator based on Internet use, we observe a weak but positive link with turnout. Following Ciornei and Østergaard-Nielsen (2020), we find that one of our cultural linkage variables is relevant: countries that belonged to the French former colonial Empire display higher turnout in consular elections-but, strikingly, we do not find the same influence in French speaking countries. This could perhaps be explained by sociohistorical links or networks playing a larger role for turnout, as compared to sharing a common language. For example, French citizens in the second Indian district, where turnout was the highest, were mostly Pondicherrians who decided to remain French in 1962, and therefore presumably share a stronger emotional connection to France (Jacquet et al. 2016). Other country-level variables, e.g., population size and democracy, do not have an impact on turnout in the consular elections.

Regarding our complementary analysis of effective turnout, the share of null and blank votes averaged $4.73 \%$ in the 129 districts. The lowest share of invalid votes (1.32\%) was observed in the second US district, whereas others reached $31.31 \%$, such as in the Guatemala district (61 blank votes and six null votes). Of the 6,867 invalid votes expressed in the 2014 consular elections, $70.26 \%$ of them were blank

\footnotetext{
12 This low figure is probably explained by the fact that French migration in Israel involves in many instances Jews returning (Aliyah), implying a stronger symbolic rupture with the origin country.
} 
votes. Very few differences emerge between our models explaining overall versus effective turnout, even if the explanatory power is slightly weaker in the later models. The party competition coefficients are slightly higher since a high share of blank votes - and therefore lower effective turnout — could indicate that voters felt dissatisfied with the political offer (Moualek 2017).

The last two models in Table 1 cover a rather different phenomenon. French voters abroad could choose to vote in-person in the host country's French consulates and embassies (or other buildings rented by the consulate services, which is more common in large electoral districts), via proxy voting, or with the Internet. Since official election results do not distinguish between in-person and proxy voting, we also group them together as the so-called ballot box voters versus 'Internet voters'. Out of the 185,422 French citizens who voted in the consular elections, a majority voted in consular buildings, while 80,115 citizens $(43.21 \%)$ voted with the Internet between 14 and 20 May 2014. This figure is lower than what has been observed in Switzerland (Germann and Serdült 2014; Germann 2021) but higher than in West Virginia (31.94\%, see Fowler 2020). It constitutes a significant decline, as compared to the 2012 legislative elections in which $57.39 \%$ and $53.54 \%$ of French voters used the Internet for the first and second rounds, respectively. ${ }^{13}$ While more than four out of ten voters used the Internet to fill in their ballots, a large variation appeared across districts. The lowest proportion of Internet voters is observed in the Comoros district $(1.68 \%)$, while they represented no less than $73.54 \%$ of the total number of voters in the fourth US district (Boston). Internet voters represented the majority of voters in 29 districts, mostly located in Western Europe and North America.

Our regression models confirm that a higher share of Internet voters is found in districts characterized by the presence of a large French community and located further away from metropolitan France. This positive impact of the geographical distance variable has also been found in the Swiss case of Internet voting abroad (see Germann and Serdült 2014). At the country level, our models indicate that a higher share of Internet voters is observed in countries with a larger French population, in member states of the European Union, in (more) democratic settings, and, unsurprisingly, in countries where there is higher Internet use.

\section{Internet voting in the 2014 consular elections}

Given this note aims to explore whether ballot box and Internet voters display different voting behavior, we look at figures of overall versus effective turnout across two different types of voters. We divide the average overall turnout $(20.85 \%)$ into ballot box voter turnout (13.9\%) and Internet voter turnout (6.95\%). The first comprises the share of ballot box votes among all registered voters, while the second contains the

\footnotetext{
13 The share of Internet voters among French living abroad was even higher for the 2013 legislative byelections: $65.1 \%$ in the first round versus $65.88 \%$ in the second round. An explanation for this decline might be that in order to vote for the European elections in 2014, French citizens abroad had to cast a vote by paper format in consular buildings.
} 
Table 2 Differences between Ballot box voters and Internet voters in the 2014 consular elections

\begin{tabular}{|c|c|c|c|c|c|}
\hline Variables & & $\begin{array}{l}\text { Overall Ballot } \\
\text { box } \\
\text { voter turnout }\end{array}$ & $\begin{array}{l}\text { Effective Ballot } \\
\text { box } \\
\text { voter turnout }\end{array}$ & $\begin{array}{l}\text { Overall Internet } \\
\text { voter turnout }\end{array}$ & $\begin{array}{l}\text { Effective } \\
\text { Internet } \\
\text { voter turnout }\end{array}$ \\
\hline \multirow[t]{8}{*}{ District-level } & \multirow[t]{2}{*}{ Community size } & $-3.929 * * *$ & $-3.731 * * *$ & -0.284 & -0.224 \\
\hline & & $(0.579)$ & $(0.570)$ & $(0.257)$ & $(0.251)$ \\
\hline & \multirow[t]{2}{*}{$\begin{array}{l}\text { Distance with } \\
\text { Paris }\end{array}$} & $-1.634 * *$ & $-1.554 * *$ & 0.177 & 0.168 \\
\hline & & $(0.749)$ & $(0.737)$ & $(0.332)$ & $(0.324)$ \\
\hline & \multirow[t]{2}{*}{ French-speaking } & -2.600 & -2.503 & -0.399 & -0.341 \\
\hline & & (1.634) & $(1.608)$ & $(0.725)$ & $(0.708)$ \\
\hline & \multirow[t]{2}{*}{ Number of lists } & $1.326 * * *$ & $1.361 * * *$ & -0.0172 & 0.0461 \\
\hline & & $(0.395)$ & $(0.388)$ & $(0.175)$ & $(0.171)$ \\
\hline \multirow[t]{6}{*}{ Country-level } & \multirow[t]{2}{*}{ Population size } & -0.227 & -0.181 & $0.254 *$ & $0.267 *$ \\
\hline & & $(0.314)$ & $(0.309)$ & $(0.139)$ & $(0.136)$ \\
\hline & \multirow[t]{2}{*}{ Internet use } & -0.00781 & -0.00439 & $0.0605^{* * *} *$ & $0.0589 * * *$ \\
\hline & & $(0.0267)$ & $(0.0263)$ & $(0.0119)$ & $(0.0116)$ \\
\hline & \multirow[t]{2}{*}{ Democracy } & -2.027 & -1.834 & -0.309 & -0.183 \\
\hline & & $(2.092)$ & $(2.058)$ & $(0.929)$ & $(0.906)$ \\
\hline \multirow[t]{4}{*}{ Control } & \multirow[t]{2}{*}{ Colonial past } & $7.282 * * *$ & $7.390 * * *$ & 0.318 & 0.388 \\
\hline & & $(1.762)$ & (1.734) & $(0.782)$ & $(0.764)$ \\
\hline & \multirow[t]{2}{*}{ EU member } & -2.134 & -1.982 & $2.192 * * *$ & $2.054 * *$ \\
\hline & & $(1.812)$ & $(1.783)$ & $(0.804)$ & $(0.785)$ \\
\hline \multirow[t]{4}{*}{ Model summary } & \multirow[t]{2}{*}{ Constant } & $60.87 * * *$ & $56.93 * * *$ & 2.034 & 0.914 \\
\hline & & $(8.279)$ & $(8.148)$ & $(3.676)$ & $(3.588)$ \\
\hline & Observations & 129 & 129 & 129 & 129 \\
\hline & R-squared & 0.575 & 0.561 & 0.465 & 0.467 \\
\hline
\end{tabular}

Standard errors in parentheses. $* * * \mathrm{p}<0.01, * * \mathrm{p}<0.05, * \mathrm{p}<0.1$

share of Internet votes among all registered voters. The lowest overall French ballot box voter turnout $(3.06 \%)$ occurred in New Zealand versus the highest $(49.74 \%)$ in the second Indian district. Overall, Internet voter turnout was the lowest at $0.34 \%$ in the Comoros district, while it reached $14.56 \%$ in Denmark.

Even if the correlation between the share of Internet voters and Internet voter turnout is rather high $(0.725$ concerning overall turnout and 0.729 for effective turnout), different dynamics are at play and a large share of Internet voters in a district does not automatically lead to higher Internet voter turnout there. For instance, $45.14 \%$ of French voters in the Czech Republic indicated their votes using the Internet, while Internet voter turnout reached $14.47 \%$ in this district. In the seventh US district (Los Angeles), the share of Internet voters was even larger (57.19\%), but Internet voter turnout was almost three times lower (5.03\%).

To explore the variation in turnout between ballot box versus Internet voters, we run several models (see Table 2). For ballot box voter turnout, both overall and effective turnout increase in districts characterized by a small French community 
with a higher degree of political mobilization, by being geographically located close to Paris, and where party competition is higher. At the country level, the only significant control variable relates to having a French colonial past.

Analyzing overall and effective Internet voter turnout figures tells completely different stories. We observe no effects of the electoral district's characteristics on either operationalization of turnout. Internet voter turnout among is higher in countries where the Internet is widely used, such as in Japan and the USA. The Internet allows emigrant voters to follow political news from their origin country and monitor domestic electoral dynamics (Metykova 2010; Oiarzabal and Reips 2012). Internet voter turnout is also significantly higher in EU countries, perhaps from an indirect impact of campaigning for the European elections that occurred a few days after the consular elections' online vote. In their comparative analysis of transnational turnout, Ciornei and Østergaard-Nielsen (2020) observed that the variables measuring the residence country's quality of democracy and the linkages between home and host countries both have an (admittedly weak) effect on turnout of emigrants from developing democracies. Contrarily, we do not observe such an impact in the 2014 French consular elections. Our variables measuring the cultural and historical environment of the French in their host countries and the electoral districts' characteristics do not significantly affect Internet voter turnout either.

Invalid votes for ballot box voters averaged $4.53 \%$, while accounting for no less than $5.58 \%$ of the total number of votes from Internet voters. Among ballot box voters, blank votes accounted for just under half (49.12\%) of the invalid votes, with the rest being null votes. Among Internet voters, almost all invalid votes were blank votes since it is technically almost impossible to express an invalid vote when voting with the Internet. As a result, the number of blank votes is almost twice as large among Internet voters as compared to ballot box voters, potentially indicating a specific form of protest vote when voters stand in front of their screen. This is not without consequences for understanding effective turnout, particularly for Internet voters. Interestingly, there are no significant differences between the models based on the two different dependent variables, even if one could expect that effective Internet voter turnout should display different explanatory patterns than overall turnout.

\section{Conclusion}

This research note has explored an understudied type of elections: the so-called consular elections in France. In these elections, French citizens living abroad-clustered in 130 extra-territorial constituencies-directly elect 443 consular councilors. In May 2014, the first consular elections occurred, and voters could choose between voting in French consulates and embassies versus with the Internet. Given the current context of the coronavirus pandemic, numerous countries are suggesting Internet voting as a solution to the issue of widespread physical proximity on election day, so this research note constitutes a timely analysis of Internet versus in-person voting turnout.

Our research design relies on analyzing official election results at the district level to observe different phenomena related to electoral participation in the 2014 
consular elections: overall and effective turnout. With 185,422 French citizens participating in the 2014 consular elections, turnout was low $(20.85 \%)$ and the share of invalid votes reached $4.7 \%$, yet these figures widely vary across districts and countries. This research note explored such data with the help of a series of independent and control variables; several used in the models have been adapted to the specificities of voters living abroad and are innovative, e.g., the variables measuring the geographic, historic, and linguistic proximity between France and the French voters' district and host country.

The Internet not only allows emigrant voters to follow political news from their origin countries and monitor domestic electoral dynamics, but also directly participate in the electoral process. Of the French citizens who participated in the 2014 consular elections, $43.21 \%$ voted with the Internet, which was more frequent for those living in large, democratic, and economically developed countries. Electoral data allow us to differentiate between the so-called ballot box versus Internet voters, and our analyses highlight that different explanatory patterns are found when distinguishing voters according to their chosen voting modality. Our research note demonstrates that, while electoral district characteristics (e.g., community size, geographical distance, party competition, etc.) influence both overall and effective ballot box voter turnout, Internet voter turnout is above all explained by the host country's economic and infrastructure development. More precisely, ballot box voter turnout is more likely to be higher in districts with a small French community with geographical and historical proximity with France and characterized by high party competition. Internet voter turnout is more likely to be higher in large and developed countries as well as in European countries.

This research note paves the road for further analyses. Due to lacking sociodemographic variables of French citizens living abroad, we know little about the impact of their characteristics on voting behavior. Future work could investigate Internet voters' individual-level behavior, and we encourage academic surveys to include voters living abroad. This would allow testing whether variables such as age, education, occupation, or those related to migration history influence the decision to vote in consular elections, participation in Internet voting, and vote choice. If external 
voting policies are redefining the geographical borders of the political community and the link between state territory and sovereignty (Lafleur 2013: 30; Collyer 2014a), consular elections are also redefining the meaning of local elections and should be more systematically studied as such. Another promising avenue for future research revolves around extending the number of cases studies and comparing results with similar elections in other settings. A starting point, for instance, could be comparing consular elections in countries such as Italy and Spain, which have similar systems to France. Highly relevant comparisons can also be conducted within the French context.

The next steps in our research project aim to include data on prior experiences of Internet voting abroad for other types of elections, e.g., the 2012 legislative elections or electing AFE members in 2006 and 2009. Another upcoming key moment for the project will be comparing the present findings on Internet voting with the next consular elections. These second consular elections were scheduled for May 2020, but, due to the coronavirus pandemic, they were postponed to May 2021. One year later, legislative elections will potentially occur, in which French citizens living abroad are also expected to be allowed to vote with the Internet.

\section{Appendix}

See Table 3.

Acknowledgements We would like to thank Victoria Finn for her helpful comments and suggestions. 


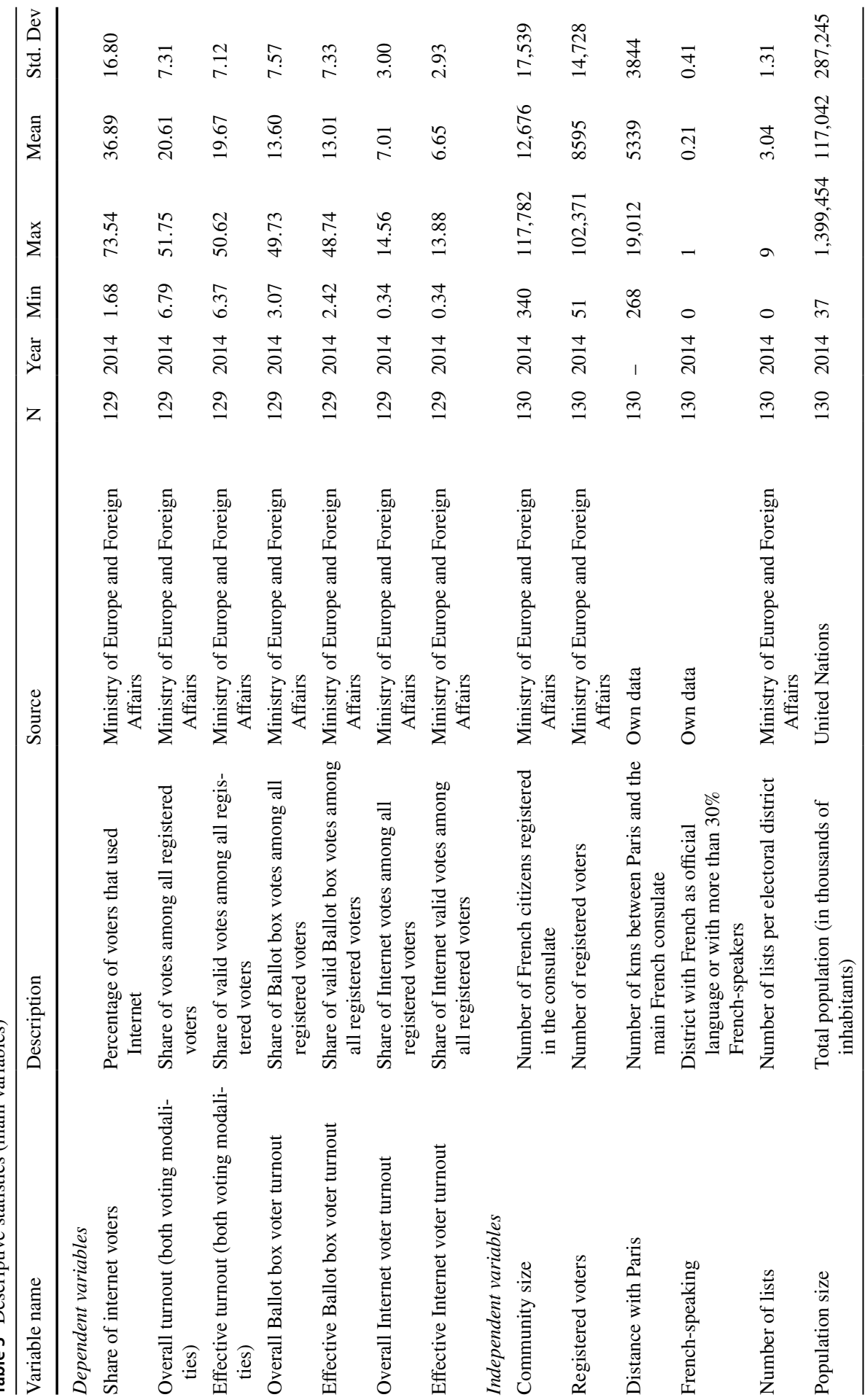




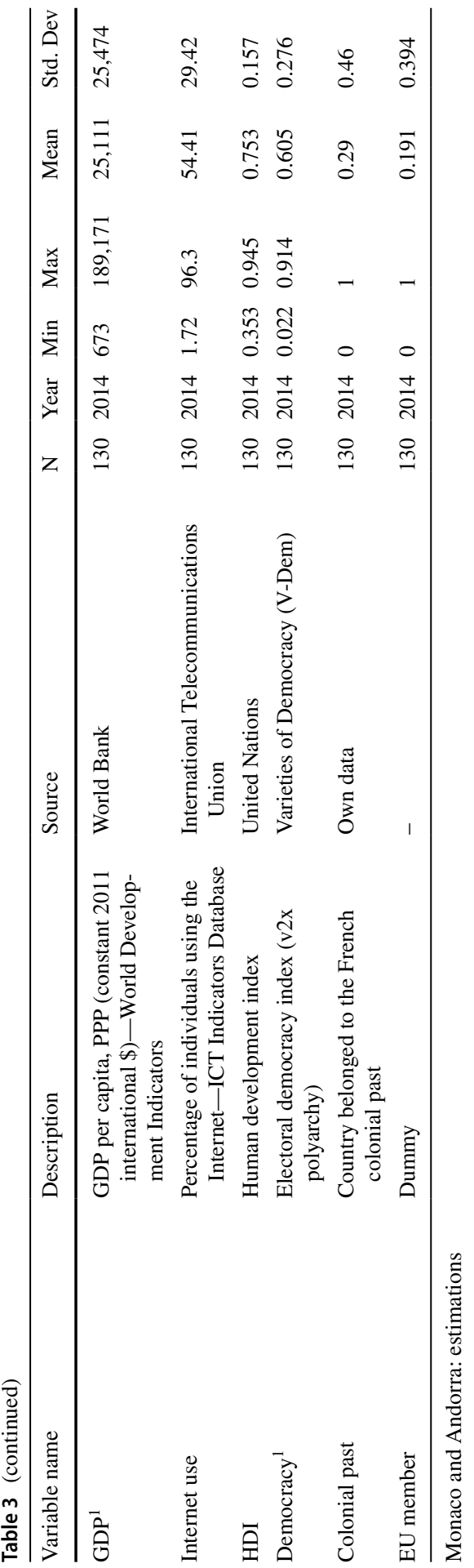




\section{References}

Allers, Maarten A., and Peter Kooreman. 2009. More evidence of the effects of voting technology on election outcomes. Public Choice 139 (1-2): 159-170.

Alvarez, Michael R., and Thad E. Hall. 2008. Electronic Elections: The Perils and Promises of Digital Democracy. Princeton: Princeton University Press.

Arrighi, Jean-Thomas. 2018. Report on political participation of mobile citizens: France. Country Report 2018/06. Florence: European University Institute.

Arrighi, Jean-Thomas., and Jean-Michel. Lafleur. 2019. Where and why can expatriates vote in regional elections? A comparative analysis of regional electoral practices in Europe and North America. Journal of ethnic and migration studies 45 (4): 517-538.

Barnes, Tiffany D., and Gabriela Rangel. 2018. Subnational Patterns of Participation: Compulsory Voting and the Conditional Impact of Institutional Design. Political Research Quarterly 71 (4): 826-841.

Bauböck, Rainer. 2007. Stakeholder citizenship and transnational political participation: a normative evaluation of external voting. Fordham Law Review. 75: 2393-2447.

Belchior, Ana Maria, Joana Azevedo, Marco Lisi, and Manuel Abrantes. 2018. Contextual reasons for emigrants' electoral participation in home country elections: the Portuguese case. Journal of Contemporary European Studies 26 (2): 197-214.

Burgess, Katrina, and Michael D. Tyburski. 2020. When parties go abroad: Explaining patterns of extraterritorial voting. Electoral Studies 66. Published online.

Caramani, Daniele, and Florian Grotz. 2015. Beyond citizenship and residence? Exploring the extension of voting rights in the age of globalization. Democratization 22 (5): 799-819.

Ciornei, Irina, and Eva Østergaard-Nielsen. 2020. Transnational turnout. Determinants of emigrant voting in home country elections. Political Geography 78. Published online.

Collard, Susan. 2013. The expatriate vote in the French presidential and legislative elections of 2012: a case of unintended consequences. Parliamentary Affairs 66 (1): 213-233.

Collard, Susan, and Elodie Fabre. 2014. Electronic voting in the French legislative elections of 2012. In Design, Development, and Use of Secure Electronic Voting Systems, ed. Dimitrios Zissis and Dimitrios Lekkas, 176-198. Hershey, PA: IGI Global.

Collyer, Michael. 2014a. A geography of extra-territorial citizenship: Explanations of external voting. Migration Studies 2 (1): 55-72.

Collyer, Michael. 2014b. Inside Out? Directly elected "special representation" of emigrants in national legislatures and the role of popular sovereignty. Political Geography 41: 64-73.

Collyer, Michael, and Zana Vathi. 2007. Patterns of extra-territorial voting. Brighton: University of Sussex.

Dahl, Robert A., and Edward R. Tufte. 1973. Size and democracy. The politics of the smaller European democracies. Stanford: Stanford University Press.

Dandoy, Régis. 2014. The impact of e-voting on turnout: Insights from the Belgian case. Proceedings of the 2014 International Conference on eDemocracy \& eGovernment (ICEDEG) (pp. 29-37), Quito (Ecuador).

Dejaeghere, Yves, and Bram Vanhoutte. 2016. Virtuous villages and sinful cities? A spatial analysis into the effects of community characteristics on turnout and blank/invalid voting in local elections in Belgium 2006-2012. Acta Politica 51: 80-101.

Deromedi, Jacky, and Yves Détraigne. 2018. Rapport sur le vote électronique, Rapport d'Information du Sénat $\mathrm{N}^{\circ} 73$, Session ordinaire de 2018-2019.

Desai, Zuheir, and Alexander Lee. 2019. Technology and protest: the political effects of electronic voting in India. Political Science Research and Methods: Published online.

Finn, Victoria. 2020. Migrant voting: here, there, in both countries, or nowhere. Citizenship Studies 24 (6): 730-750.

Fowler, Anthony. 2020. Promises and perils of mobile voting. Election Law Journal 19 (3): 418-431.

Frassa, Christophe-André, and Jean-Yves Leconte. 2015. Rapport sur le bilan de l'application de la loi n²013-659 du 22 juillet 2013 relative à la représentation des Français établis hors de France, Rapport d'Information du Sénat $\mathrm{N}^{\circ} 481$, Session ordinaire de 2014-2015.

Fujiwara, Thomas. 2015. Voting Technology, Political Responsiveness, and Infant Health: Evidence from Brazil. Econometrica 83 (2): 423-464.

Galam, Serge. 2018. Unavowed Abstention Can Overturn Poll Predictions. Frontiers in Physics 6 (24): 1-8. Gamlen, Alan. 2019. Human geopolitics: States, emigrants, and the rise of diaspora institutions. Oxford: Oxford University Press. 
Gamlen, Alan, Michael E. Cummings, and Paul M. Vaaler. 2019. Explaining the rise of diaspora institutions. Journal of Ethnic and Migration Studies 45 (4): 492-516.

Garriaud-Maylam, Joëlle. 2010. Un pays pionnier. La représentation politique des expatriés en France. In Loin des yeux, près du cœur. Les États et leurs expatriés, eds. Stéphane Dufoix, Carinne Guerassimoff and Anne de Tinguy, 108-114. Paris: Presses de SciencesPo.

Germann, Micha, and Uwe Serdült. 2014. Internet Voting for Expatriates: The Swiss Case. eJournal of eDemocracy \& Open Government 6(2): 197-215.

Germann, Micha. 2020. Making Votes Count with Internet Voting. Political Behavior: Published online.

Germann, Micha. 2021. Internet voting increases expatriate voter turnout. Government Information Quarterly: Published online.

Goldberg, Andreas C., and Simon Lanz. 2019. Living abroad, voting as if at home? Electoral motivations of expatriates. Migration Studies: Published online.

Hartmann, Christof. 2015. Expatriates as voters? The new dynamics of external voting in Sub-Saharan Africa. Democratization 22 (5): 906-926.

Hutcheson, Derek S., and Jean-Thomas. Arrighi. 2015. 'Keeping Pandora's (ballot) box half-shut': a comparative inquiry into the institutional limits of external voting in EU Member States. Democratization 22 (5): 884-905.

Jacquet, Antoine, Aurélie Varrel, and Audrey Richard-Ferroudji. 2016. Quand les migrants sont français: La population française de Pondichéry. Cahiers des IFRE 3: 58-67.

Katz, Gabriel, and Ines Levin. 2018. A general model of abstention under compulsory voting. Political Science Research and Methods 6: 489-508.

Kernalegenn, Tudi, and Cédric. Pellen. 2020. En Marche, French expatriates! The booming emergence of a new political actor among French residents overseas in the 2017 elections. In Political Parties Abroad: A New Arena for Party Politics, ed. Tudi Kernalegenn and Émilie. Van Haute, 96-114. London: Routledge.

Kimball, David, C. Owens and Katherine McAndrew Keeney. 2004. Unrecorded Votes and Political Representation. In Counting Votes: Lessons from the 2000 Presidential Election in Florida, ed. Robert P. Watson. Gainesville: University Press of Florida.

Lafleur, Jean-Michel. 2013. Transnational politics and the state: The external voting rights of diasporas. New York and London: Routledge.

Francophonie, La. 2014. The French Language worldwide 2014. Paris: Éditions Nathan.

Lequesne, Christian. 2020. La diaspora française de Londres à l'heure du Brexit. Les études du CER I: 250.

Moualek, Jérémie. 2017. Votes that are (really) not like others? The many usages of blank and null votes. Revue française de science politique 67 (6): 1153-1166.

Metykova, Monika. 2010. Only a mouse click away from home: Transnational practices of Eastern European migrants in the United Kingdom. Social Identities 16 (3): 325-338.

Nicolau, Jairo. 2015. Impact of electronic voting machines on blank votes and null votes in Brazilian elections in 1998. Brazilian Political Science Review 9 (3): 3-20.

Oiarzabal, Pedro, and Ulf-Dietrich. Reips. 2012. Migration and diaspora in the age of information and communication technologies. Journal of Ethnic and Migration Studies 38 (9): 1333-1338.

Pellen, Cédric. 2013. À la conquête de l'Amérique. Revue française de science politique 63 (6): 1137-1162.

Petitpas, Adrien, Julien M. Jaquet, and Pascal Sciarini. 2020. Does E-Voting matter for turnout, and to whom? Electoral Studies: Published online.

Serdült, Uwe, Micha Germann, Fernando Mendez, Maja Harris, and Alicia Portenier. 2015. Who Are the Internet Voters? Review Article. In Electronic Government and Electronic Participation, ed. Efthimios Tambouris, et al., 27-41. Amsterdam: IOS Press.

Stewart, Charles III. 2006. Residual vote in the 2004 election. Election Law Journal 5: 158-169.

Turcu, Anca, and Robert Urbatsch. 2015. Diffusion of diaspora enfranchisement norms: A multinational study. Comparative Political Studies 48 (4): 407-437.

VanHaute, Émilie., and Tudi Kernalegenn. 2020. A framework of analysis for political parties abroad. In Political Parties Abroad: A New Arena for Party Politics, ed. Tudi Kernalegenn and Émilie. Van Haute, 238-254. London: Routledge.

Publisher's Note Springer Nature remains neutral with regard to jurisdictional claims in published maps and institutional affiliations. 